\title{
Morphology and Molecular Phylogeny of Pseudocyrtohymenides lacunae nov. gen., nov. spec. (Ciliophora: Oxytrichidae) from South Korea
}

\author{
Jae-Ho JUNG ${ }^{1,2, *}$, Kyung-Min PARK ${ }^{1,3, *}$, and Gi-Sik MIN ${ }^{1}$ \\ ${ }^{1}$ Department of Biological Sciences, Inha University, Incheon, South Korea; ${ }^{2}$ Department of Biology, Gangneung-Wonju National \\ University, Gangneung, South Korea; ${ }^{3}$ Division of Life Sciences, Korea Polar Research Institute, Incheon, South Korea \\ "These authors equally contributed to this work.
}

\begin{abstract}
We collected an 18-cirri oxytrichid ciliate from the brackish lagoon Songjiho, South Korea, in March 2012. Based on analyses of morphological and molecular attributes, we conclude that it is new genus and species. Pseudocyrtohymenides lacunae nov. gen., nov. spec. has similar morphological attributes to the genus Pseudocyrtohymena, however, the former species lacks caudal cirri. The sequence similarity of the nuclear small subunit ribosomal RNA (SSU rRNA) gene was 99.4\% (10 nt difference) between Pseudocyrtohymenides lacunae and Pseudocyrtohymena koreana (type species).
\end{abstract}

Key words: New genus, new species, Korea, SSU rRNA gene, protargol impregnation, Sporadotrichida

\section{INTRODUCTION}

Oxytrichids with 18 frontal-ventral-transverse (FVT) cirri are a diverse group of ciliates (Berger 1999). The type genus Oxytricha Bory de Saint-Vincent in Lamouroux et al., 1824 has the following morphological diagnosis: usually 18 FVT cirri; one left and one right marginal cirral row; dorsal kinety 3 fragmented (Oxytricha pattern) or non-fragmented (Urosomoida pattern); caudal cirri present; and undulating membranes in Oxytricha pattern (Berger 1999). Although

Address for correspondence: Gi-Sik Min, Department of Biological Sciences, Inha University, Incheon 402-751, South Korea; Tel: +8232-860-7692; Fax: +82-32-874-6737; Cell Phone: +82-10-62190752; Email: mingisik@inha.ac.kr they have limited variation in traits such as 18 FVT cirri, new taxa are constantly being discovered, even at the genus level (Kumar et al. 2015, Foissner 2016, Jung et al. 2016a). In the Oxytrichidae Ehrenberg, 1838, it is generally found that combinations of morphological attributes (see above) define new genera, rather than single characteristics (e.g., Aponotohymena Foissner, 2016, Architricha Gupta et al., 2006, Monomicrocaryon Foissner, 2016, Pseudocyrtohymena Jung et al., 2015, Quadristicha Foissner, 2016).

Of the recently established genera in Oxytrichidae, our new species has similar morphological attributes to the genus Pseudocyrtohymena that consists of the sole species $P$. koreana (monotypy) and mainly differs from the genus Oxytricha by its undulating membranes (Cyrtohymena pattern vs. Oxytricha pattern) (Jung et 
al. 2015). Pseudocyrtohymena has a non-fragmented dorsal kinety 3 (Urosomoida pattern) and reduced caudal cirri (Jung et al. 2015).

During an investigation of ciliate diversity in Korea, we collected a Pseudocyrtohymena-like sp. from a brackish lagoon and identified it based on live observation, protargol impregnation, and the small subunit (SSU) rRNA gene. From our results, we conclude it is a new genus and species. Here, we report the morphological description and phylogenetic relationships of this new species.

\section{MATERIALS AND METHODS}

\section{Sample collection and identification}

We collected surface waters from the brackish lagoon Songjiho (38²0'09"N, 128 30'57"E), South Korea, in March 2012. The surface waters $\left(5.3 \mathrm{psu}, 9.9^{\circ} \mathrm{C}\right)$ were obtained from eastern side, near inflow of saline water, on the lagoon. Clonal cultures were maintained in Petri dishes and also in 50-mL tissue culture flasks (Greiner Bio-One, Frickenhausen, Germany) at room temperature (ca. $18^{\circ} \mathrm{C}$ ). Rice grains were added to the cultures to enrich bacteria as a food resource for protozoa (flagellates) including ciliates. Living specimens were observed under a light microscope (Leica DM2500, Wetzlar, Germany) at magnifications ranging from $50 \times$ to $1000 \times$. Protargol impregnation was performed to observe infraciliatures and nuclear apparatus (Foissner 1991).

Terminology and classification are according to Berger (1999), Lynn (2008), and Jung et al. (2015).

\section{PCR amplification and sequencing}

Specimens were washed several times with distilled water in order to isolate a single cell. Genomic DNA was extracted using a RED-Extract-N-Amp Tissue PCR Kit (Sigma, St. Louis, MO, USA) according to the manufacturer's protocol. A modified New EukA (5'-CTG GTT GAT YCT GCC AGT-3') forward primer (Jung et al. 2012) and LSU rev3 (Sonnenberg et al. 2007) reverse primer were used for PCR amplification of the nearly complete nuclear SSU rRNA gene. The optimized PCR conditions were as follows: denaturation at $94^{\circ} \mathrm{C}$ for $3 \mathrm{~min}$, followed by 35 cycles of denaturation at $94^{\circ} \mathrm{C}$ for $30 \mathrm{~s}$, annealing at $58^{\circ} \mathrm{C}$ for $30 \mathrm{~s}$, extension at $72^{\circ} \mathrm{C}$ for $4 \mathrm{~min}$, and a final extension step at $72^{\circ} \mathrm{C}$ for $7 \mathrm{~min}$. The PCR products were purified using a QIAquick ${ }^{\circledR}$ PCR Purification Kit (Qiagen, Hilden, Germany). The following two internal primers were used for sequencing: $18 \mathrm{~S}+810$ and $18 \mathrm{~S}-300$ (Jung et al. 2011). DNA sequencing was performed using an ABI 3700 sequencer (Applied Biosystems, Foster City, CA, USA).

\section{Phylogenetic analysis}

Nucleotide sequences were assembled using Geneious v6.1.6 (Biomatters Ltd, Auckland). Pairwise sequence similarity was calculated using MEGA 5.2 (Tamura et al. 2011). For analyses of phylogenetic relationships, we retrieved the sequences of 42 hypotrichs from GenBank. The sequences were aligned using Clustal X
1.81 (Jeanmougin et al. 1998) implemented in BioEdit (Hall 1999). We evaluated phylogenetic relationships by using maximum likelihood (ML) and Bayesian inference (BI). The maximum likelihood analysis was conducted using PhyML 3.1 (Guindon et al. 2010). Confidence in the analyses was assessed using the bootstrap procedure, with 1000 replications for ML. BI assessment was performed using MrBayes 3.2.6 (Ronquist et al. 2012), simulating a Markov chain Monte Carlo (MCMC) for 1,000,000 generations, 300,000 of which were discarded as the burn-in. Furthermore, to determine the appropriate DNA substitution model for ML and BI analyses, we used the Akaike information criterion to identify the best-fit model according to the jModelTest 2.1.10 (Darriba et al. 2012). The model selected was GTR + I (0.7180) + G (0.4770). The bootstrap values and posterior probablities, above $70 \%$ and 0.95 , respectively, were statistically interpreted as sufficient evidences, given the bootstrap values of $\geq 70 \%$ likely corresponds to $\geq 95 \%$ accuracy (Alfaro $e t$ al. 2003; Guindon et al. 2010).

\section{RESULTS}

\section{Pseudocyrtohymenides nov. gen.}

Diagnosis: Oxytrichidae with undulating membranes in Australocirrus-Cyrtohymena pattern; body flexible, colorless cytoplasm; cortical granules present; non-fragmented dorsal kinety 3 and one or more dorsomarginal kineties (Urosomoida pattern); caudal cirri lacking.

Type species: Pseudocyrtohymenides lacunae nov. spec.

Etymology: Composite of the generic name Pseudocyrtohymena and the Greek suffix -ides (similar), meaning a ciliate similar to Pseudocyrtohymena; masculine gender.

Pseudocyrtohymenides lacunae nov. spec.

Diagnosis: Size in vivo $120-165 \mu \mathrm{m} \times 25-50 \mu \mathrm{m}$; body flexible and slightly contractile, slender to ellipsoidal in shape, grayish to slightly yellowish under low magnification; two macronuclear nodules with approximately two micronuclei; contractile vacuole at left mid-body; cortical granules spherical, yellowish, approximately $1 \mu \mathrm{m}$ in diameter, irregularly distributed on cortex; on average, 37 adoral membranelles, 18 FVT cirri, and 23 left and 27 right marginal cirri; undulating membranes in Australocirrus-Cyrtohymena pattern; four or five dorsal kineties composed of three dorsal and one or two dorsomarginal rows (Urosomoida pattern); dorsal kinety 3 non-fragmented; caudal cirri absent.

Type locality: Songjiho lagoon $\left(38^{\circ} 20^{\prime} 09^{\prime \prime} \mathrm{N}\right.$, $\left.128^{\circ} 30^{\prime} 57^{\prime \prime E}\right)$, South Korea near the East Sea; salinity of $5.3 \mathrm{psu}$.

Type materials: The holotype (NIBRPR0000104 263) and three paratype (NIBRPR0000104264-NIBR 
PR0000104266) slides with protargol-impregnated specimens were deposited in the National Institute of Biological Resources (NIBR), South Korea. The other three paratype slides (MABIK PR00042645-00042647) have been deposited in the National Marine Biodiversity Institute of Korea (MABIK), South Korea. The holotype and other relevant specimens were marked using circles on the bottoms of the slides.

Etymology: The species-group name "lacunae" is derived from the Latin noun lacuna (lagoon) in the singular genitive case, denoting where the specimens were discovered.

Description: Size in vivo $120-165 \mu \mathrm{m} \times 25-50 \mu \mathrm{m}$ $(\sim 3.2: 1, n=5$; Figs $1 \mathrm{~A} ; 2 \mathrm{~A}-\mathrm{D})$, on average $105.1 \mu \mathrm{m}$ $\times 36.6 \mu \mathrm{m}$ in protargol preparations (Table 1; Figs $1 \mathrm{C}$, D; 2F, G). Body flexible and slightly contractile; cell colour grayish to slightly yellowish under low magnification. Invariably two macronuclear nodules, elliptical to elongated oval, $14.0-19.5 \mu \mathrm{m} \times 4.5-8.5 \mu \mathrm{m}$ (stained); one to four micronuclei, spherical, 1.5-3.0 $\mu \mathrm{m} \times 1.0-2.5 \mu \mathrm{m}$ (stained). Contractile vacuole on left side of mid-body, approximately $10 \mu \mathrm{m}$ in diameter without conspicuous collecting canals (Figs 1A; 2A). Cortical granules irregularly distributed on cortex, yellowish, spherical, approximately $1 \mu \mathrm{m}$ in diameter (Figs 1B; 2C, E). Cell inclusions with food vacuoles (bacteria, small protists) and granular inclusions. Crawling moderately fast on bottom of Petri dish.

Table 1. Morphometric data of Pseudocyrtohymenides lacunae nov. gen., nov. spec.

\begin{tabular}{|c|c|c|c|c|c|c|c|}
\hline Characteristics (protargol-impregnated specimens) & Min & Max & Mean & M & $\mathrm{SD}$ & $\mathrm{CV}$ & $n$ \\
\hline Body, length & 92 & 122 & 105.1 & 103.6 & 8.6 & 8.2 & 21 \\
\hline Body, width & 26 & 52 & 36.6 & 35.3 & 6.4 & 17.4 & 21 \\
\hline Adoral zone of membranelles, length & 35 & 46 & 39.7 & 39.8 & 2.7 & 6.9 & 21 \\
\hline Percentage $(\%)$ of body length occupied by adoral zone & 33.3 & 41.0 & 37.8 & 37.9 & 2.3 & 6.1 & 21 \\
\hline Longest adoral membranelles, length & 4.5 & 6.0 & 5.3 & 5.2 & 0.4 & 8.4 & 21 \\
\hline Adoral membranelles, number & 31 & 44 & 37.3 & 37 & 3.3 & 8.8 & 21 \\
\hline Frontal cirri, number & 3 & 3 & 3 & 3 & 0 & 0 & 21 \\
\hline Frontoventral cirri, number & 4 & 4 & 4 & 4 & 0 & 0 & 21 \\
\hline Buccal cirrus, number & 1 & 1 & 1 & 1 & 0 & 0 & 21 \\
\hline Ventral cirri, number & 5 & 9 & 5.4 & 5 & 1.0 & 19.0 & 21 \\
\hline Transverse cirri, number & 3 & 6 & 5 & 5 & 0.6 & 11.7 & 21 \\
\hline Posterior end of cell to rearmost transverse cirrus, distance & 9 & 15 & 12.6 & 12.8 & 1.6 & 12.5 & 21 \\
\hline Left marginal cirri, number & 19 & 27 & 22.6 & 22 & 2.3 & 10.1 & 21 \\
\hline Right marginal cirri, number & 23 & 33 & 27.1 & 27 & 2.8 & 10.3 & 21 \\
\hline Dorsal kineties, number & 4 & 5 & 5 & 5 & 0.2 & 4.4 & 21 \\
\hline Bristles in dorsal kinety 1 , number & 13 & 22 & 17.6 & 17 & 2.7 & 15.2 & 21 \\
\hline Bristles in dorsal kinety 2 , number & 17 & 25 & 21.5 & 21 & 2.2 & 10.2 & 21 \\
\hline Bristles in dorsal kinety 3 , number & 17 & 26 & 21.6 & 22 & 2.4 & 11.2 & 21 \\
\hline Bristles in dorsomarginal row 1 , number & 12 & 19 & 16.2 & 17 & 2.1 & 12.8 & 21 \\
\hline Bristles in dorsomarginal row 2 , number & 1 & 3 & 1.5 & 1 & 0.6 & 41.7 & 20 \\
\hline Total number of bristles & 62 & 92 & 78.3 & 79 & 7.1 & 9.1 & 21 \\
\hline Macronucleus nodules, number & 2 & 2 & 2 & 2 & 0 & 0 & 21 \\
\hline Macronucleus nodules, length ${ }^{\mathrm{a}}$ & 14.0 & 19.5 & 16 & 15.4 & 1.6 & 9.7 & 21 \\
\hline Macronucleus nodules, width ${ }^{\mathrm{a}}$ & 4.5 & 8.5 & 6.8 & 6.8 & 1.1 & 15.7 & 21 \\
\hline Micronuclei, number & 1 & 4 & 1.7 & 1 & 0.9 & 52.6 & 21 \\
\hline Micronuclei, length $^{\mathrm{a}}$ & 1.5 & 3.0 & 2.2 & 2.3 & 0.4 & 17.4 & 21 \\
\hline Micronuclei, with ${ }^{\mathrm{a}}$ & 1.0 & 2.5 & 1.8 & 1.9 & 0.3 & 16.3 & 21 \\
\hline
\end{tabular}

All measurements in $\mu \mathrm{m}$.

${ }^{a}$ A macro- or micronucleus was randomly chosen in each cell.

$\mathrm{CV}$, coefficient of variation (\%); M, median; Max, maximum; Min, minimum; $n$, number of specimens investigated; SD, standard deviation. 

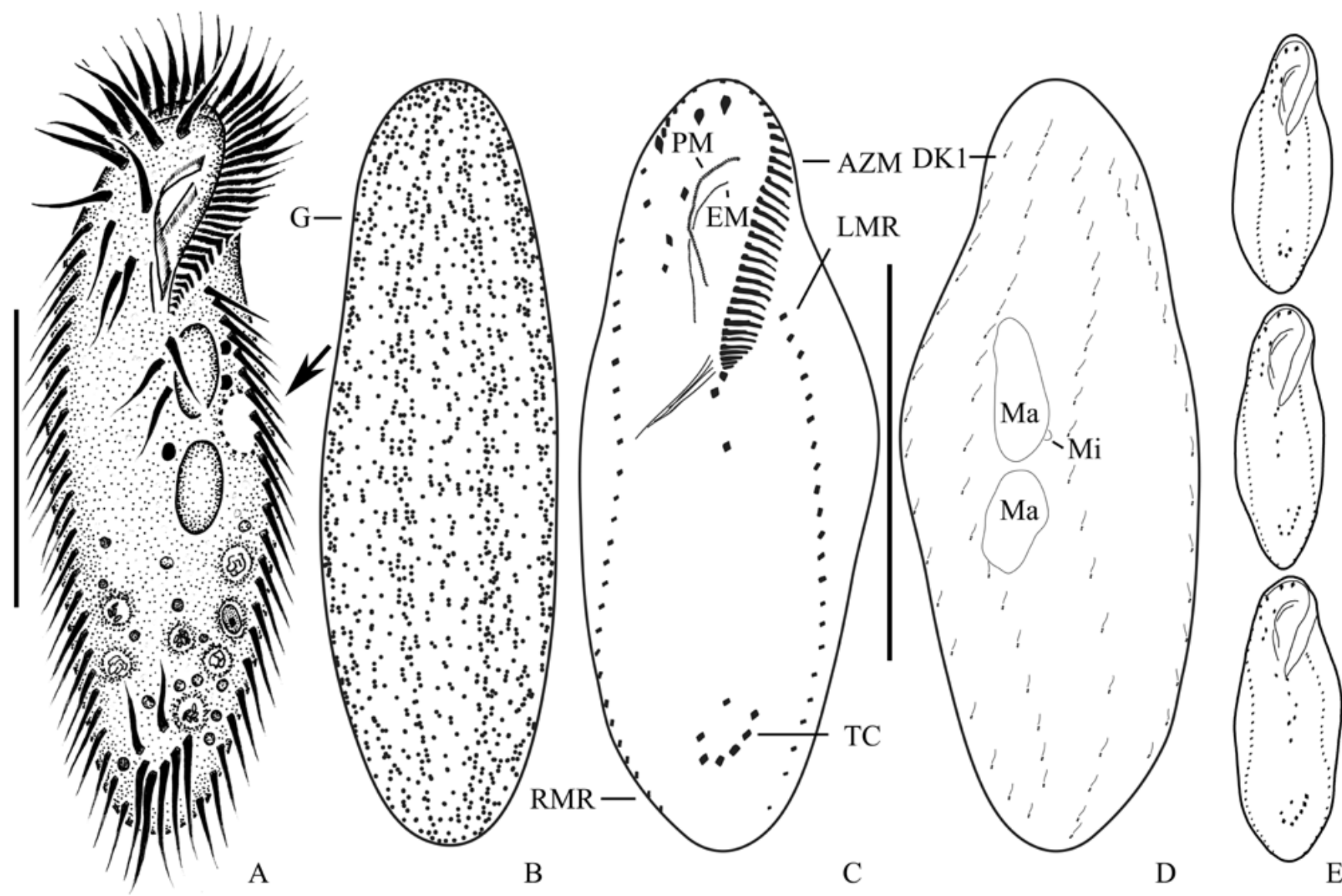

Fig. 1. Pseudocyrtohymenides lacunae nov. gen., nov. spec. (A, B), living specimens and (C-E), after protargol impregnation. (A, B), ventral (A) and dorsal (B) views of representative specimens; arrow denotes contractile vacuole. (C, D), ventral (C) and dorsal (D) views of the holotype specimen. (E), ventral views showing the variation of frontal-ventral-transverse cirri. AZM, adoral zone of membranelles; DK1, dorsal kinety 1; EM, endoral membrane; G, cortical granules; LMR, left marginal cirral row; Ma, macronuclear nodules; Mi, micronuclei; PM, paroral membrane; RMR, right marginal cirral row; TC, transverse cirri. Scale bars: $50 \mu \mathrm{m}$.

All cirri relatively fine, mostly $12-21 \mu \mathrm{m}$ long in vivo; frontal and transverse cirri 18-21 $\mu \mathrm{m}$ long; other cirri $12 \mu \mathrm{m}$ long (Figs 1A; 2D, G). Arrangement of FVT cirri as in other flexible 18-cirri hypotrichs; usually three frontal, four frontoventral, one buccal, five ventral, and five transverse cirri. A few cells show variation in the number of cirri, ranging from 16 to 23; frontal, frontoventral, buccal cirri invariably eight; ventral and transverse cirri 5-9 and 3-6 cirri, respectively; transverse cirri obliquely arranged, slightly J-shaped. One left and one right marginal row, composed of 19-27 cirri and 23-33 cirri, respectively; both posterior ends never connected, terminate at similar level. Usually five dorsal kineties, that is constantly three bipolar kineties and usually two (20 of 21 specimens analysed) dorsomarginal kineties; dorsal kinety 4 posteriorly slightly shortened (12-19 bristles); kinety 5 conspicuously posteriorly shortened, if present, composed of 1-3 bristles (Figs 1D; 2F); dorsal kinety 3 non-fragmented; dorsal cilia approximately $2.5-3.0 \mu \mathrm{m}$ long (Fig. 2E). Caudal cirri absent.

Adoral zone of membranelles approximately $38 \%$ of body length in impregnated specimens; base of the largest membranelles approximately $5 \mu \mathrm{m}$ long; cilia of membranelles approximately $13 \mu \mathrm{m}$ long. Paroral and endoral membrane in Australocirrus-Cyrtohymena pattern, namely, anterior part of paroral membrane distinctly curved in leftward direction and recurved slightly distally; undulating membranes intersect in mid-buccal cavity (Figs 1C, E; 2H).

Phylogenetic analyses: The SSU rDNA sequence of Pseudocyrtohymenides lacunae was $1,576 \mathrm{bp}$ in 

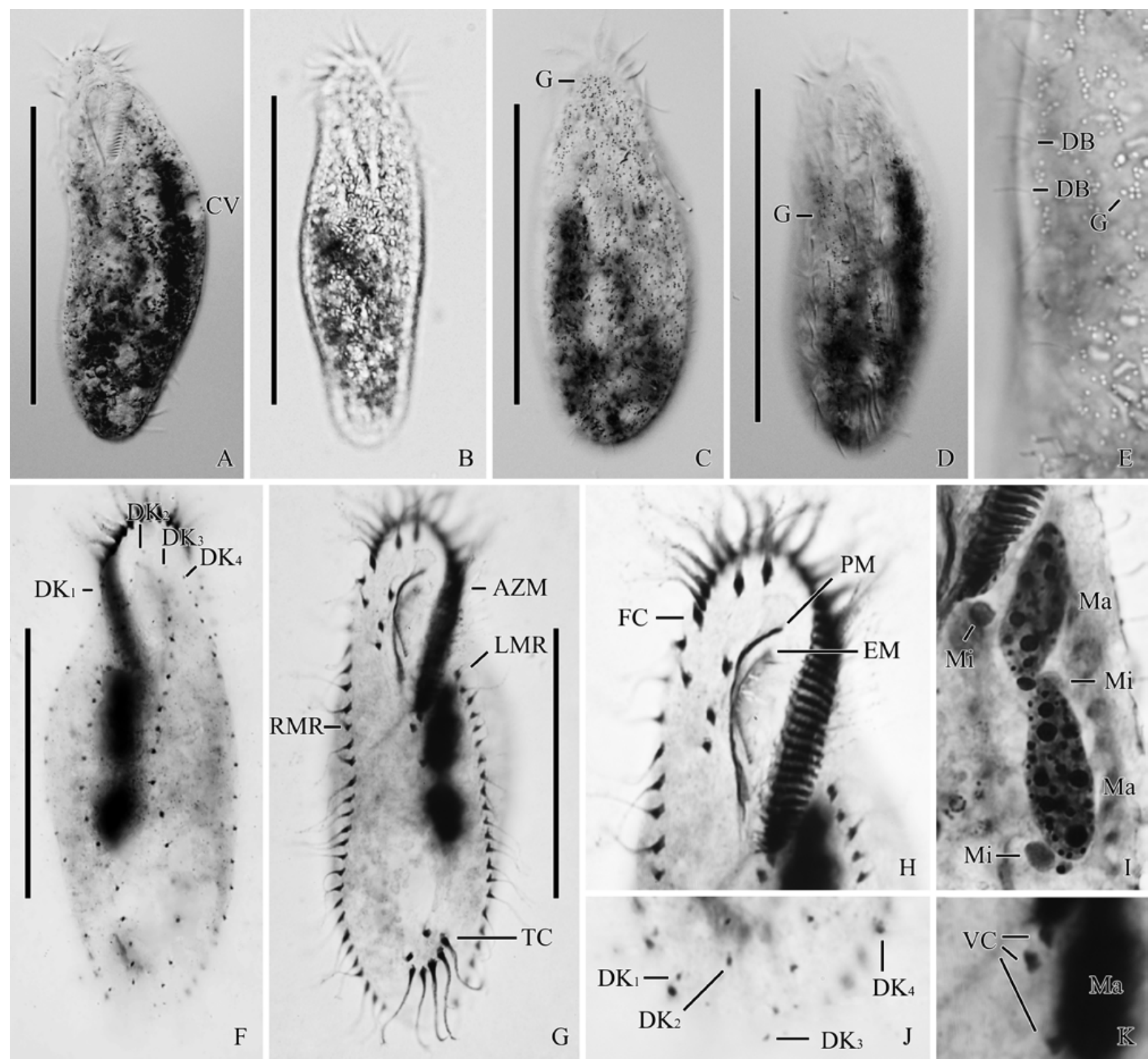

Fig. 2. Pseudocyrtohymenides lacunae nov. gen., nov. spec. (A-E), living specimens; (F-K), after protargol impregnation. (A, D), ventral views of representative specimens. $(\mathrm{B}, \mathrm{C}, \mathrm{E})$, dorsal views showing cortical granules and dorsal bristles. (F-K), dorsal (F, J) and ventral $(\mathrm{G}-\mathrm{I}, \mathrm{K})$ views showing infraciliature and nuclear apparatus. AZM, adoral zone of membranelles; $\mathrm{CV}$, contractile vacuole; DB, dorsal bristle; $\mathrm{DK}_{1-4}$, dorsal kineties 1-4; EM, endoral membrane; FC, frontal cirrus; G, cortical granules; LMR, left marginal cirral row; Ma, macronuclear nodules; Mi, micronuclei; PM, paroral membrane; RMR, right marginal cirral row; TC, transverse cirri; VC, ventral cirri. Scale bars: $100 \mu \mathrm{m}$ in $\mathrm{A}-\mathrm{D}$ and $50 \mu \mathrm{m}$ in $\mathrm{F}-\mathrm{G}$.

length (GenBank accession number: MF319121). The sequence similarity between Pseudocyrtohymena koreana and Pseudocyrtohymenides lacunae was $99.4 \%$ (10 nt difference). In the phylogenetic tree (Fig. 3), although Pseudocyrtohymenides nov. gen. clustered with the genus Pseudocyrtohymena, the supporting values were not significant (posterior probability of 0.52 , bootstrap value of $<50 \%$ ). The clade PseudocyrtohymenaPseudocyrtohymenides showed a sister relationship with Pseudogastrostyla flava-Rubrioxytricha haematoplasma-R. ferruginea-Ponturostyla enigmatica (posterior probability of 0.85 , bootstrap value of $<50 \%$ ). 
In addition, the clade Pseudocyrtohymena-Pseudocyrtohymenides did not cluster with Cyrtohymena species.

\section{DISCUSSION}

\section{Morphological comparison to related species}

The genus Pseudocyrtohymena Jung et al., 2015 was established as monotypic (type species: P. koreana). The type species conspicuously differs from Pseudocyrtohymenides lacunae nov. spec. by caudal cirri (1-3 vs. 0; Jung et al. 2015). The type species has the caudal cirri only at the end of dorsal kinety 3 , while the dorsal kineties 1 and 2 do not form the cirri at the ends during the morphogenesis (Jung et al. 2015). As reported by Jung et al. (2015), Pseudocyrtohymena does not produce the fragmentation of dorsal kinety anlage 3 (Urosomoida pattern), that is, dorsal kinety 3 could be considered as kinety 4 in the typical oxytrichids, which splits into two kineties (single fragmentation) (Berger 1999). In terms of the undulating membranes, the two species have similar type (Australocirrus-Cyrtohymena pattern). Their paroral membranes are slightly distally recurved that place them intermediate position between Australocirrus and Cyrtohymena pattern (Kumar and Foissner 2015).

Of the members in Oxytrichidae, Rubrioxytricha indica Naqvi et al. 2006, as previously compared by Jung et al. (2015), shares similar morphological characteristics to Pseudocyrtohymena and Pseudocyrtohymenides (see Table 2; Naqvi et al. 2006). However, $R$. indica can be separated from $P$. lacunae by body size (on average of stained cells, $69 \times 27 \mu \mathrm{m}$ vs. $105 \times 37 \mu \mathrm{m})$, contractile vacuole ( 3 vs. 1 ), cortical granules (dark greenish vs. yellowish), adoral membranelles (27-31 vs. 31-44), and caudal cirri (1 vs. 0) (Naqvi et al. 2006). The colourless cytoplasm and the reduced caudal cirrus of $R$. indica suggests this species could be considered as a congener to Pseudocyrtohymena. However, until the genetic material of $R$. indica is obtained, we maintain its current classification.

\section{Molecular phylogeny of Pseudocyrtohymenides lacu- nae}

In our phylogenetic tree (Fig. 3), P. lacunae clustered with the species $P$. koreana. However, the supporting values on the clade Pseudocyrtohymena-Pseudocyrtohymenides were not significant enough to convince us that these two species are congeners. Unfortunately, the low values of oxytrichids on the nodes for these analyses have been easily found before in oxytrichids (e.g., Chen et al. 2015, Fan et al. 2015, Jung et al. 2016a). Although the urostylids, one of several large groups in the hypotrichs, have been analysed using the same gene, their supporting values are higher than the oxytrichids (e.g., Jo et al. 2015, Jung et al. 2016b, Pan et al. 2016). To improve the resolution of phylogenetic relationships in the oxytrichids, more sampling of other oxytrichids or expanding the genes targeted for the analyses is required (for instance, see Zhao et al. 2012, Gao et al. 2014).

The clade Pseudocyrtohymena-Pseudocyrtohymenides clustered with the group Pseudogastrostyla flava-Rubrioxytricha haematoplasma-R. ferruginea-

Table 2. Comparison of morphological features of Pseudocyrtohymenides lacunae nov. spec. to closely related species.

\begin{tabular}{|c|c|c|c|}
\hline Characteristics $^{\mathrm{a}}$ & $\begin{array}{l}\text { Pseudocyrtohymenides lacunae } \\
\text { nov. spec. }\end{array}$ & $\begin{array}{l}\text { Pseudocyrtohymena koreana } \\
\text { (type species) }\end{array}$ & Rubrioxytricha indica \\
\hline Body, size & $105 \times 37$ & $112 \times 47$ & $69 \times 27$ \\
\hline Cytoplasm, colour & colourless & colourless & colourless \\
\hline Cortical granules, colour & yellowish & yellowish & dark greenish \\
\hline Contractile vacuole, number & 1 & 1 & 3 \\
\hline Adoral membranelles, number & $31-44$ & $38-53$ & $27-31$ \\
\hline Caudal cirri, number (in each dorsal kinety $1-3$ ) & $0(0,0,0)$ & $1-3(0,0,1-3)$ & $1(0,0,1)$ \\
\hline Dorsal kineties, number ${ }^{\mathrm{b}}$ & 4 or 5 (usually 4 ) & 5 & 5 \\
\hline Fragmentation of dorsal kinety 3 & absent & absent & absent \\
\hline Data source & this study & Jung et al. (2015) & Naqvi et al. (2006) \\
\hline
\end{tabular}

All measurements in $\mu \mathrm{m}$.

${ }^{\text {aD }}$ ata based on protargol-impregnated specimens.

${ }^{b}$ Including dorsomarginal rows. 

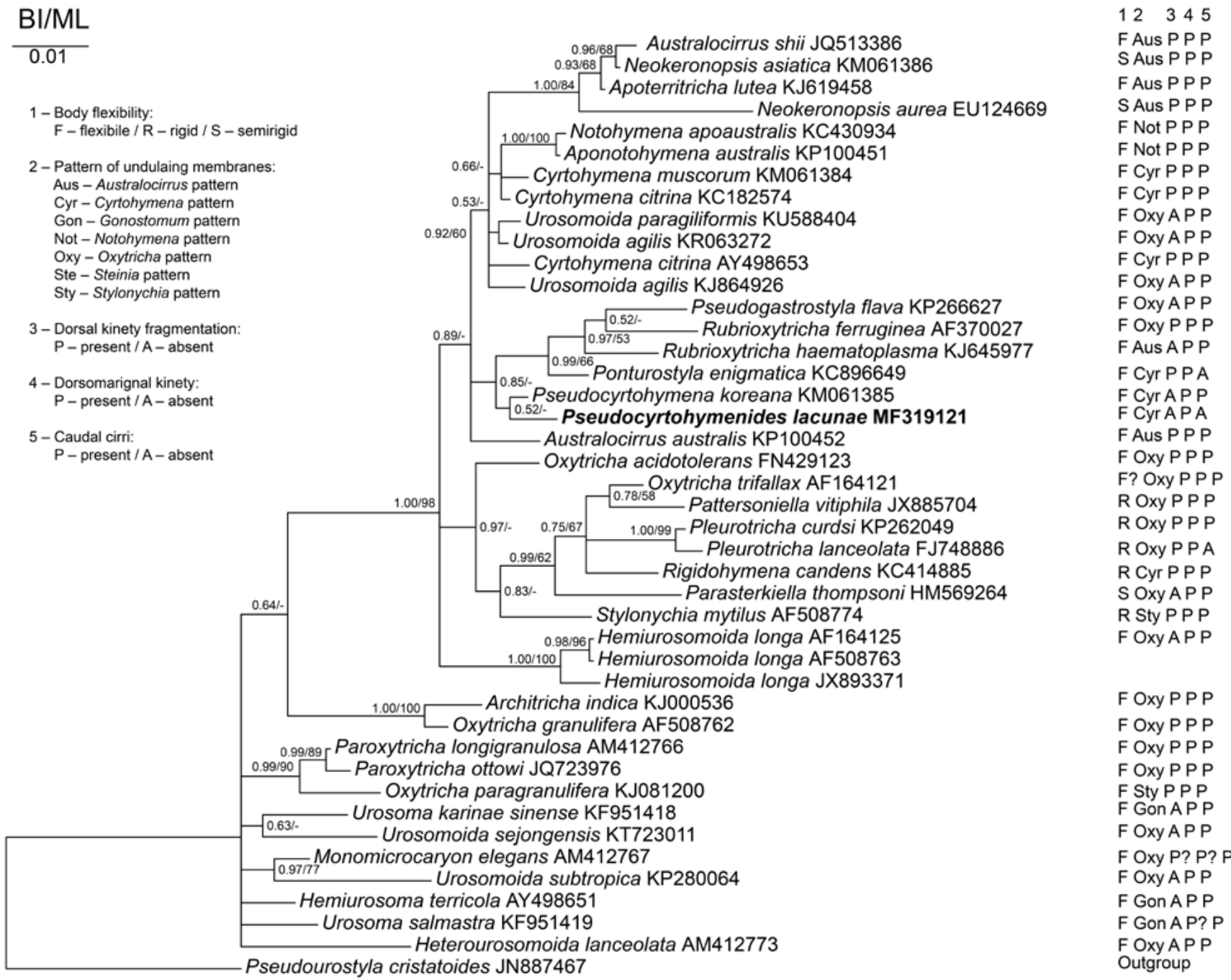

Fig. 3. Phylogenetic tree of SSU rRNA gene sequences, showing the position of Pseudocyrtohymenides lacunae nov. spec. on the basis of Maximum Likelihood (ML) and Bayesian Inference (BI). Bootstrap values of ML and posterior probabilities of BI were denoted on each interior branch. If the values of the bootstrap and the posterior probability were less than $50 \%$ and 0.50 , respectively, they were excluded. The scale bar represents one nucleotide substitution per $100 \mathrm{nt}$.

Ponturostyla enigmatica (Fig. 3). These groups all have the reduced number of caudal cirri in common; Pseudocyrtohymena has 1-3 caudal cirri and Pseudocyrtohymenides lacks the caudal cirri ( 1 in P. flava; 0 or 1 in R. haematoplasma; 1 or 2 in R. ferruginea; 0 in P. enigmatica) (Berger 1999, Song 2001, Fan et al. 2015). Based on the phylogenetic tree (Fig. 3; see the terms on the upper left), morphological attributes such as '2-undulation membranes' or '3-dorsal kinety fragmentation' did not exclusively separate these genera. This was expected, as with other oxytrichids, the genus Pseudocyrtohymenides is defined as a combination of characteristics not individual ones.
Acknowledgements. This work was supported by grants from the National Institute of Biological Resources (NIBR), funded by the Ministry of Environment (MOE) of the Republic of Korea (NIBR 2013-02-001); the Korea Polar Research Institute (KOPRI, PE 17900); and the National Research Foundation of Korea (NFK) funded by the Korea government (MSIP; Ministry of Science, ICT \& Future Planing) (No. NRF - 2017 R1C1B5017183).

\section{REFERENCES}

Alfaro M. E., Zoller S., Lutzoni F. (2003) Bayes or bootstrap? A simulation study comparing the performance of Bayesian Markov chain Monte Carlo sampling and bootstrapping in assessing phylogenetic confidence. Mol. Biol. Evol. 20: 255-266 
Berger H. (1999) Monograph of the Oxytrichidae (Ciliophora, Hypotrichia). Monogr. Biol. 78: i-xii, 1-1080

Chen W., Chen X., Li L., Warren A., Lin X. (2015) Morphology, morphogenesis and molecular phylogeny of an oxytrichid ciliate, Rubrioxytricha haematoplasma (Blatterer \& Foissner, 1990) Berger, 1999 (Ciliophora, Hypotricha). Int. J. Syst. Evol. Microbiol. 65: 309-320

Darriba D., Taboada G. L., Doallo R., Posada D. (2012) jModelTest 2: more models, new heuristics and parallel computing. Nat. Methods 9: 772

Fan Y., Zhao X., Hu X., Miao M., Warren A., Song W. (2015) Taxonomy and molecular phylogeny of two novel ciliates, with establishment of a new genus, Pseudogastrostyla n. g. (Ciliophora, Hypotrichia, Oxytrichidae). Eur. J. Protistol. 51: 374-385

Foissner W. (1991) Basic light and scanning electron microscopic methods for taxonomic studies of ciliated protozoa. Eur. J. Protistol. 27: 313-330

Foissner W. (2016) Terrestrial and semiterrestrial ciliates (Protozoa, Ciliophora) from Venezuela and Galápagos. Denisia 35: 1-912

Gao F., Gao S., Wang P., Katz L. A., Song W. (2014) Phylogenetic analyses of cyclidiids (Protista, Ciliophora, Scuticociliatia) based on multiple genes suggest their close relationship with thigmotrichids. Mol. Phylogenet. Evol. 75: 219-226

Guindon S., Dufayard J. F., Lefort V., Anisimova M., Hordijk W., Gascuel O. (2010) New algorithms and methods to estimate maximum-likelihood phylogenies: Assessing the performance of PhyML 3.0. Syst. Biol. 59: 307-321

Hall T. (1999) BioEdit: A user-friendly biological sequence alignment editor and analysis program for Windows 95/98/NT. Nucleic Acids Symp. Ser. 41: 95-98

Jeanmougin F., Thompson J. D., Gouy M., Higgins D. G., Gibson T. J. (1998) Multiple sequence alignment with Clustal X. Trends Biochem. Sci. 23: 403-405

Jo E., Jung J.-H., Min G.-S. (2015) Morphology and molecular phylogeny of two new brackish water ciliates of Bakuella (Ciliophora: Urostylida: Bakuellidae) from South Korea. J. Eukaryot. Microbiol. 62: 799-809

Jung J.-H., Park K.-M., Min G.-S. (2012) Morphology, morphogenesis, and molecular phylogeny of a new brackish water ciliate, Pseudourostyla cristatoides n. sp., from Songjiho lagoon on the coast of East Sea, South Korea. Zootaxa 3334: 42-54

Jung J.-H., Park K.-M., Min G.-S. (2015) Morphology and molecular phylogeny of Pseudocyrtohymena koreana n. g., n. sp. and Antarctic Neokeronopsis asiatica Foissner et al., 2010 (Ciliophora, Sporadotrichida), with a brief discussion of the Cyrtohymena undulating membranes pattern. J. Eukaryot. Microbiol. 62: 280-297

Jung J.-H., Park K.-M., Kim S. (2016b) Morphology and molecular phylogeny of the soil ciliate Anteholosticha rectangula nov. spec. from King George Island, maritime Antarctica. Acta Protozool. 55: 89-99
Jung J.-H., Baek Y.-S., Kim S., Choi H.-G. (2016a) Morphology and molecular phylogeny of a new freshwater ciliate Urosomoida sejongensis n. sp. (Ciliophora, Sporadotrichida, Oxytrichidae) from King George Island, Antarctica. Zootaxa 4072: 254-262

Jung J.-H., Baek Y.-S., Kim S., Choi H.-G., Min G.-S. (2011) A new marine ciliate, Metaurostylopsis antarctica nov. spec. (Ciliophora, Urostylida) from the Antarctic Ocean. Acta Protozool. 50: 289-300

Kumar S., Foissner W. (2015) Biogeographic specializations of two large hypotrich ciliates: Australocirrus shii and A. australis and proposed synonymy of Australocirrus and Cyrtohymenides. Eur. J. Protistol. 51: 210-228

Kumar S., Kamra K., Bharti D., La Terza A., Sehgal N., Warren A., Sapra G. R. (2015) Morphology, morphogenesis, and molecular phylogeny of Sterkiella tetracirrata n. sp. (Ciliophora, Oxytrichidae), from the Silent Valley National Park, India. Eur. J. Protistol. 51: $86-97$

Lynn D. H. (2008) The ciliated protozoa: Characterization, classification, and guide to the literature. Springer, New York

Naqvi I., Gupta R., Borgohain P., Sapra G. R. (2006) Morphology and morphogenesis of Rubrioxytricha indica n. sp. (Ciliophora : Hypotrichida). Acta Protozool. 45: 53-64

Pan X., Fan Y., Gao F., Qiu Z., Al-Farraj S. A., Warren A., Shao C. (2016) Morphology and systematics of two freshwater urostylid ciliates, with description of a new species (Protista, Ciliophora, Hypotrichia). Eur. J. Protistol. 52: 73-84

Ronquist F., Teslenko M., van der Mark P., Ayres D. L., Darling A., Höhna S., Larget B., Liu L., Suchard M. A., Huelsenbeck J. P. (2012) MrBayes 3.2: Efficient Bayesian phylogenetic inference and model choice across a large model space. Syst. Biol. 61: $539-542$

Song W. (2001) Morphology and morphogenesis of the marine ciliate Ponturostyla enigmatica (Dragesco \& Dragesco-Kernéis, 1986) Jankowski, 1989 (Ciliophora, Hypotrichida, Oxytrichidae). Eur. J. Protistol. 37: 181-197

Sonnenberg R., Nolte A. W., Tautz D. (2007) An evaluation of LSU rDNA D1-D2 sequences for their use in species identification. Front. Zool. 4: 6

Tamura K., Peterson D., Peterson N., Stecher G., Nei M., Kumar S. (2011) MEGA5: Molecular evolutionary genetics analysis using maximum likelihood, evolutionary distance, and maximum parsimony methods. Mol. Biol. Evol. 28: 2731-2739

Zhao Y., Gao F., Li J., Yi Z., Warren A. (2012) Phylogenetic analyses on the tintinnid ciliates (Protozoa, Ciliophora) based on multigene sequence data. Acta Protozool. 51: 319-328

Received on $22^{\text {th }}$ January, 2017; revised on $11^{\text {th }}$ April, 2017; accepted on $8^{\text {th }}$ June, 2017 